\title{
Implementasi Strategi Student Team Achievement Divisions Dalam Pembelajaran Tematik Terpadu Di SD Darus Sholah Jember
}

\author{
Nasilah \\ SD Darus Sholah Jember \\ nazila.qurani@gmail.com \\ Ahmad Winarno \\ IAIN Jember \\ ahmad.winarno@iain-jember.ac.id
}

DOI:10.35719/educare.v2i1.49

\begin{abstract}
This research was conducted at SD Darus Sholah, Jember which aims to answer the main problems related to the implementation of the Student Team Achievement Divisions learning strategy in integrated thematic learning. The problem studied in this research is the Implementation of the Student Team Achievement Divisions Strategy in integrated thematic learning at SD Darus Sholah, Jember. This research approach uses a qualitative approach with the type of phenomenological research. Methods of data collection using interviews, observation and documentation. Data analysis used the interactive model of Miles and Huberman, with the process of data collection, condensation, data display, and data verification. To test the validity of the data using triangulation. The results of this study indicate that: 1) At the presentation stage, the teacher starts with story material, reviews previous material, and learning activities in teams. 2) The teacher prepares a worksheet as a guide for group work and each member can contribute, the teacher makes observations, provides guidance, motivation, and assistance if needed. 3) Individual tests in groups. 4) Score development for individuals, the teacher combines the previous score with the final score. 5) Appreciation for the team is based on the assessment of individuals in the group so that the process of group assessment recapitulation is based on individual assessment of each group.
\end{abstract}

Keywords: STAD Model; Learning Thematic; Primary school 


\begin{abstract}
Abstrak
Penelitian ini dilakukan di SD Darus Sholah Jember yang bertujuan untuk menjawab pokok permasalahan berkaitan dengan penerapan strategi belajar Student Team Achievement Divisions dalam pembelajaran tematik terpadu. Permasalahan yang dikaji dalam penelitian ini, Implementasi Strategi Student Team Achievement Divisions dalam pembelajaran tematik terpadu di SD Darus Sholah Jember. Pendekatan penelitian ini menggunakan pendekatan kualitatif dengan jenis penelitian fenomenologis. Metode pengumpulan data menggunakan wawancara, observasi dan dokumentasi. Analisis data menggunakan model analisis interaktif Miles dan Huberman, dengan proses data collection, condensation, data display, and data verifiying. Untuk menguji keabsahan data menggunakan trianggulasi. Hasil penelitian ini menunjukkan bahwa: 1) Pada tahap presentasi, guru memulai dengan materi cerita, mereview ulang materi sebelumnya, dan kegiatan belajar dalam tim. 2) Guru menyiapkan lembaran kerja sebagai pedoman kerja kelompok dan setiap anggota dapat berkontribusi, guru melakukan pengamatan, memberikan bimbingan, motivasi, dan bantuan jika diperlukan. 3) Tes individu dalam kelompok. 4) Skor pengembangan bagi individu, guru menggabungkan skor nilai sebelumnya dengan skor akhir. 5) Penghargaan bagi tim mendasarkan kepada penilaian terhadap individu dalam kelompok sehingga proses rekapitulasi penilaian kelompok, didasarkan kepada penilaian individu masing-masing kelompok.
\end{abstract}

\title{
Kata Kunci: Model STAD; Pembelajaran Tematik; Sekolah Dasar
}

\section{PENDAHULUAN}

Pembelajaran merupakan bagian penting dari keberhasilan tujuan pendidikan. Ada beberapa elemen yang mempengaruhi keberhasilan sebuah pembelajaran, diantaranya pemilihan model, perencanaan, pelaksanaan, ketersediaan media, sarana prasarana, hingga proses evaluasi (alat ukur). Hal ini sesuai dengan Permendikbud Nomor 65 Tahun 2013 tentang Standar Proses Pendidikan Dasar dan Menengah. Pasal 1 ayat (1) menyebutkan bahwa "Standar Proses Pendidikan Dasar dan Menengah selanjutnya disebut Standar Proses yang merupakan kriteria mengenai pelaksanaan pembelajaran pada satuan pendidikan dasar dan menengah guna untuk mencapai kompetensi lulusan". 
Permendikbud Nomor 66 Tahun 2013 tentang Standar Penilaian Pendidikan Pasal 1 ayat (1) menyebutkan bahwa "Penilaian hasil belajar peserta didik pada jenjang pendidikan dasar dan menengah dilaksanakan berdasarkan standar penilaian pendidikan yang berlaku secara nasional". Pemilihan model pembelajaran juga haruslah tepat, sebab dengan model yang tepat maka akan menghasilkan sebuah proses pembelajaran yang efektif.

Dari hasil observasi di SD Darus Sholah terutama di Kelas IV, peneliti menemukan berbagai masalah yang berkaitan dengan masalah individu dan masalah kelompok, masalah individu tersebut berkaitan dengan karakter seorang anak yang cukup bervariasi. Ada anak-anak yang sering menganggu teman, malas mengerjakan tugas, meminta didampingi secara berlebihan, merasa paling bisa, kurang bertanggung jawab, dan tidak percaya diri. Sedangkan untuk masalah kelompok yaitu, mudah lelah, terjadi persaingan yang tidak sehat antar kelompok, semangat kerjasama yang rendah. ${ }^{2}$

Hal tersebut sesuai dengan apa yang disampaikan Dune. Menurut dia, Untuk masalah individual, biasanya ada empat hal, diantaranya tingkah laku yang ingin mendapatkan perhatian orang lain, tingkah laku yang ingin menunjukkan kekuatan, tingkah laku yang bertujuan menyakiti orang lain dan peragaan ketidakmampuan. Sedangkan masalah yang terjadi dalam kelompok, menurut Dune, ada enam kategori, yakni kelas kurang kondusif, kelas mereaksi negatif terhadap salah satu seorang anggotanya, membesarkan hati anggota kelompok kelas yang justru melanggar norma kelompok, kelompok cenderung mudah dialihkan perhatiannya dari tugas yang tengah dikerjakan, semangat kerja rendah, dan kelas kurang mampu menyesuaikan diri dengan keadaan baru. ${ }^{3}$

\footnotetext{
${ }^{1}$ Permendikbud Nomor 66 Tahun 2013 tentang Standar Penilaian Pendidikan

${ }^{2}$ Observasi di kelas IV, Senin 4 Januari 2019

${ }^{3}$ Ricard Dunne dan Ted Wragg. Pembelajaran Efektif. Terjemahan Anwar Yasin, (Jakarta: Gramedia Widiasarana Indonesia. 1996), 80.
} 
Untuk itulah diperlukan peran aktif guru sebagai fasilitator dalam model pembelajaran tersebut, dalam mendampingi, membimbing, dan mengarahkan peserta didik agar mencapai tujuan yang telah ditetapkan. Sebagai fasilitator, guru harus membantu kesulitan yang dialami peserta didiknya, dan menyarankan untuk membangun kerjasama. Berdasarkan observasi yang dilakukan peneliti, model pembelajaran di SD Darus Sholah pada awalnya menggunakan model pembelajaran klasik, yakni ceramah. Sehingga pembelajaran berlangsung membosankan, kelas tidak kondusif dan murid tidak memiliki kesempatan untuk bertanya. Akhirnya, dari proses evaluasi yang dilakukan oleh kepala sekolah bersama bidang kurikulum, guru di SD Darus Sholah diminta untuk lebih kreatif menerapkan model pembelajaran, agar kelas semakin hidup dan murid tidak lagi jenuh di kelas.

Penerapan model pembelajaran dengan menggunakan cooperative learning belum sepenuhnya berjalan maksimal. Fakta di lapangan, meski telah diminta untuk lebih kreatif dalam memilih model pembelajaran, guru ternyata belum sepenuhnya menggunakan model pembelajaran cooperative learning, akibatnya terjadi kejenuhan di kelas, murid mudah mengantuk, serta tidak ada interaksi antara guru dan peserta didik. Guru kembali menjadi center of learning, sehingga semua proses pembelajaran di kelas, benar-benar terpusat kepada guru. Namun lambat laun dengan berjalannya waktu, guru mulai menguasai penuh model pembelajaran cooperative learning terutama tipe Student Teams Achivement Division (STAD). Sehingga hal ini dapat berpengaruh terhadap berjalannya proses pembelajaran dengan baik.

Selain itu, peneliti kemudian mengamati kegiatan proses pembelajaran di Kelas I dan IV yang menggunakan strategi STAD. Dimana, saat proses pembelajaran berlangsung cukup efektif dan kelas cenderung kondusif. Peserta didik benar-benar fokus dalam kegiatan proses pembelajaran. Selain itu, muncul kerjasama antar masing-masing anggota kelompok untuk menyelesaikan tugas yang telah diberikan oleh guru. 
Untuk memudahkan peneliti dalam mengkaji masalah, ada beberapa grand teori yang digunakan dalam penelitian ini, yaitu teori milik Robert E Slavin tentang Cooperative Learning. Menurut Slavin pembelajaran kooperatif merujuk berbagai macam metode pembelajaran, dimana para peserta didik bekerja dalam kelompok-kelompok kecil untuk saling membantu satu sama lainnya dalam mempelajari mata pelajaran. Slavin menambahkan, dalam kelas kooperatif para peserta didik diharapkan dapat saling membantu, saling mendiskusikan, dan berargumentasi, untuk mengasah pengetahuan yang mereka kuasai saat itu, dan menutup kesenjangan dalam pemahaman masing-masing. ${ }^{4}$

Selain teori milik Slavin, penelitian juga menggunakan teori model pembelajaran strategi STAD milik Rusman. Strategi STAD merupakan variasi pembelajaran kooperatif yang memacu peserta didik agar saling mendorong dan membantu satu sama lain untuk menguasai keterampilan yang diajarkan oleh guru. ${ }^{5}$ Sedangkan menurut David W. Johnson and Roger T. Johnson. Dia mengatakan bahwa, setidaknya ada lima unsur dalam pembelajaran kooperatif, yakni positive inter dependence (ketergantungan positif), face-to-face (tatap muka), individual accountability (tanggung jawab individu), social skills (keterampilan sosial), dan group processing (pemrosesan group). ${ }^{6}$

Dari pemaparan konteks penelitian inilah kemudian, peneliti ingin meneliti lebih jauh dan mendalam, seperti apa implementasi strategi Student Team Achivement Division (STAD) dalam pembelajaran tematik terpadu di SD Darus Sholah Kabupaten Jember.

\footnotetext{
${ }^{4}$ Robert E Slavin. Cooperative Learning: Theory, Reserach and Practice. (Allymand Bacon. London. 2005). 4.

${ }^{5}$ Rusman, Model-Model Pembelajaran: Mengembangkan Profesionalisme Guru. (Jakarta: Raja Grafindo Persada, 2012), 214

${ }^{6}$ David W. Johnson and Roger T. Johnson. Cooperative Learning (University of Minnesot $a$, USA, tt) 3-4
} 


\section{METODE PENELITIAN}

Metode yang digunakan dalam penelitian ini adalah pendekatan kualitatif, metode penelitian kualitatif sering disebut metode penelitian naturalistik karena penelitiannnya dilakukan pada kondisi alamiah (natural setting $)^{7}$. Adapun jenis penelitian ini menggunakan kualitatif fenomenologis (fenomena dan kenyataan). Dimana penelitian ini akan difokuskan untuk memahami, menggali, dan menafsirkan arti dari peristiwa-peristiwa, fenomena-fenomena dan hubungan dengan orang-orang yang ada dalam situasi tertentu. ${ }^{8}$ Lokasi penelitian ini di SD Darus Sholah Kecamatan Kaliwates, Kabupaten Jember. Adapun informan dalam penelitian ini yakni guru kelas, murid, serta wakil kurikulum. Metode pengumpulan data dalam penelitian ini menggunakan wawancara, observasi dan dokumentasi. Sedangkan analisis data menggunakan teknik analisis interaktif Miles dan Huberman, yakni proses analisis data meliputi data collection, data condensation, data display, and data verifiying. ${ }^{9}$ Uji keabsahan data dalam penelitian ini peneliti menggunakan tekhnik trianggulasi.

\section{HASIL DAN PEMBAHASAN TEMUAN}

\section{HASIL TEMUAN}

Presentasi Kelas Dalam Pembelajaran Tematik Terpadu Tema 7 Sub Tema 1 Kelas I Dan Tema 8 Sub Tema 2 Kelas IV SD Darus Sholah Jember

Di SD Darus Sholah sebagaimana hasil wawancara peneliti, sebelum guru melakukan presentasi kepada peserta didik, guru menyiapkan materi terlebih dahulu. Seperti disampaikan oleh Guru Kelas 4C. Berdasarkan hasil wawancara, observasi di SD Darus Sholah terkait dengan presentasi kelas dalam pembelajaran tematik yaitu sebelum memulai kegiatan pembelajaran

\footnotetext{
${ }^{7}$ Sugiyono, Metode Penelitian Kuantitatif, Kualitatif, dan $R \& D$ (Bandung:CV Alfabeta,2017)8

${ }^{8}$ Iskandar, Metodologi Penelitian Kualitatif, (Jakarta: GP.Press. 2009) 51

${ }^{9}$ Miles and Hubberman, Qualitative Data Analysis (United State of Amerika: Arizona State University, 2014), 8-10..
} 
guru menyiapkan materi terlebih dahulu. Guru membuat materi pembelajaran dengan model lembar kerja peserta didik yang dibuat secara berkelompok. Penyiapan materi itu penting karena memiliki tujuan untuk memudahkan saat proses pembelajaran di kelas. Jika dilihat dari persiapan yang ada, guru SD Darus Sholah baik kelas 1 dan kelas 4 sudah menuangkannya ke dalam RPP. Setelah menyiapkan RPP, kemudian guru memulai kegiatan presentasi kelas saat proses pembelajaran, dimana guru memulainya dengan mengarahkan peserta didik terkait materi yang akan dibahas. Hal ini untuk memudahkan peserta didik dalam proses pembelajaran. Kondisi tersebut mencerminkan dengan teori yang ada.

\section{Belajar Tim Dalam Pembelajaran Tematik Terpadu Tema 7 Sub Tema} 1 Kelas I Dan Tema 8 Sub Tema 2 Kelas IV SD Darus Sholah Jember

Di kelas 4C SD Darus Sholah, berdasarkan hasil wawancara peneliti, pembagian kelompok tersebut berdasarkan dua pertimbangan tersebut, yakni kemampuan dan jenis kelamin. Sehingga, anggota masing-masing kelompok terjadi variasi antara tingkat kemampuan dan jenis kelamin. ${ }^{10}$ Berdasarkan hasil wawancara, observasi dan dokumentasi terkait dengan belajar tim dalam pembelajaran tematik di SD Darus Sholah yaitu: 1) Kegiatan belajar dalam tim di SD Darus Sholah baik kelas 1 maupun kelas 4 sudah berjalan dengan baik dan sesuai dengan teori yang ada. Hal itu tercermin, setelah kegiatan presentasi kelas, guru kemudian membagi murid kedalam beberapa kelompok kecil dengan beranggotakan 4-5 orang peserta. Dimana, pembagian kelompok tersebut baik di kelas 1 dan 4 berdasarkan pertimbangan nilai dan jenis kelamin.2) Setelah dibagi kedalam kelompok kecil, guru kemudian memberikan perintah kepada peserta didik sesuai dengan tema yang telah ditentukan. Kondisi tersebut sudah sesuai dengan sintaks STAD yang ada dan kegiatan belajar itu sudah ditulis didalam rancangan pelaksanaan pembelajaran.

\footnotetext{
${ }^{10}$ Wawancara Guru Kelas 4C, Agung Udayana, Tanggal 2 Maret 2019.
} 


\section{Tes Individu Dalam Pembelajaran Tematik Terpadu Tema 7 Sub Tema}

\section{Kelas I Dan Tema 8 Sub Tema 2 Kelas IV SD Darus Sholah Jember.}

Pelaksanaan tes individual dikelas 1 dan kelas 4 SD Darus Sholah sudah sesuai dan berjalan dengan baik. Dimana tes individu itu dilaksanakan oleh guru setelah melaksanakan satu atau dua kali penyajian kelas dan bekerja serta berlatih dalam kelompok. Saat pelaksanaan tes individual, peserta didik tidak diperbolehkan untuk saling membantu dalam mengerjakan kuis/soal. Hal ini dilakukan untuk mengetahui sejauh mana tingkat kemampuan masing-masing individu setelah belajar dalam kelompok. Untuk pelaksanaan tes individu baik di kelas 1 maupun kelas 4 SD Darus Sholah dilakukan dengan dua macam cara yakni tes verbal dan tulis.

\section{Skor Pengembangan Individu Dalam Pembelajaran Tematik Terpadu Tema 7 Sub Tema 1 Kelas I dan Tema 8 Sub Tema 2 Kelas IV SD Darus Sholah Jember}

Skor pengembangan individu merupakan sintaks keempat dalam pembelajaran kooperatif dengan strategi STAD. Skor pengembangan individu untuk melihat sejauh mana perkembangan nilai peserta didik setelah menggunakan strategi STAD. Di kelas 1D SD Darus Sholah, skor pengembangan individu merupakan gabungan skor tes akhir dengan skor dasar. Skor dasar diambilkan dari tes awal yang dilakukan guru pada saat membagi kelompok. Dari hasil laporan skor perkembangan individu yang dimiliki oleh guru, memang menunjukkan adanya peningkatan nilai setiap peserta didik. Peningkatan tersebut terlihat dari semakin baiknya nilai yang diraih peserta didik terutama aspek pengetahuan.

Sementara di kelas 4C SD Darus Sholah, skor pengembangan individu merupakan penggabungan dari nilai sebelum dilaksanakannya pembelajaran kooperatif dengan strategi STAD, kemudian pada saat proses, dan nilai akhir. "Kita gabung nilainya dari sebelum dilaksanakan STAD, kemudian pada saat proses, dan nilai terakhir. Pada saat proses itulah yang 
juga menentukan sebab hampir di setiap sub tema, mereka selalu mengerjakan tugas yang telah saya berikan. Nah, nilai-nilai ini yang kemudian kita gabung menjadi skor peningkatan individu" 11

Skor pengembangan individu di SD Darus Sholah baik di Kelas 1 dan 4 sudah sesuai dengan teori yang adanya. Dimana untuk Skor pengembangan individu merupakan gabungan skor tes akhir dengan skor dasar. Skor dasar diambilkan dari tes awal yang dilakukan guru pada saat membagi kelompok. Jika dilihat dari skor perkembangan individu yang, menunjukkan adanya peningkatan nilai setiap peserta didik, itu artinya pembelajaran kooperatif dengan strategi STAD di SD Darus Sholah sudah berjalan dengan baik.

\section{Penghargaan tim Dalam Pembelajaran Tematik Terpadu Tema 7 Sub Tema 1 Kelas I dan Tema 8 sub Tema 2 Kelas IV SD Darus Sholah Jember}

Sintaks terakhir dalam strategi STAD adalah penghargaan tim. Penghargaan atau pengakuan tim ini didasarkan pada nilai rata-rata yang diperoleh tim. Penghargaan ini diberikan agar dapat memotivasi para peserta didik. Penggunaan sistem skor dalam model STAD adalah untuk lebih menekankan kemajuan dari pada persentase jawaban yang benar. Dengan model begini, akan memacu peserta didik untuk lebih maju dan lebih baik dari kegiatan belajar sebelumnya.

Di kelas 1D SD Darus Sholah, guru memberikan apresiasi atau penghargaan kinerja dalam tim dengan memberikan hadiah kepada kelompok terbaik. Hadiah tersebut diwujudkan dalam bentuk alat tulis dan buku. ${ }^{12}$ Sementara di kelas $4 \mathrm{C}$, guru juga memberikan penghargaan kepada kelompok terbaik berupa alat tulis dan buku. Dimana setiap peserta didik masing-masing mendapatkan satu buah buku dan satu alat tulis.

\footnotetext{
${ }^{11}$ Wawancara Guru Kelas 4C, Agung Udayana, Tanggal 2 Maret 2019.

${ }^{12}$ Observasi di kelas 4 C SD Darus Sholah.
} 
Penghargaan tim dalam pembelajaran kooperatif dengan strategi STAD baik di Kelas 1 maupun kelas 4 di SD Darus Sholah sudah baik. Hal itu terlihat dari bentuk guru yang memberikan apresiasi atau penghargaan kinerja dalam tim dengan memberikan hadiah kepada kelompok terbaik. Hadiah tersebut berupa buku dan alat tulis. Hadiah dimaksudkan agar kelompok lebih aktif dan bersaing lebih baik di masa yang akan datang.

\section{PEMBAHASAN TEMUAN}

Presentasi Kelas Dalam Pembelajaran Tematik Terpadu Tema 7 Sub Tema 1 Kelas I Dan Tema 8 Sub Tema 2 Kelas Iv Sd Darus Sholah Jember

Presentasi kelas merupakan sintaks atau tahapan pertama dalam pembelajaran kooperatif dengan tipe STAD. Presentasi kelas merupakan kegiatan yang dilakukan guru sebelum memulai proses pembelajaran. Di SD Darus Sholah, guru melakukan proses presentasi kelas dengan model klasikal, dimana guru menerangkan tujuan umum pembelajaran serta materi yang akan dibahas. Sebelum melakukan proses tersebut, guru sebelumnya telah menyiapkan rancangan proses pembelajarannya. Rancangan tersebut merupakan bagian tanggung jawab guru serta bukti bahwa guru telah siap melaksanakan proses pembelajaran.

Hal ini sebagaimana diungkapkan Abdul Majid, bahwa ada lima komponen utama dalam pembelajaran kooperatif dengan menggunakan metode STAD. Yang pertama adalah presentasi kelas. Penyajian kelas merupakan penyajian materi yang dilakukan guru secara klasikal dengan menggunakan presentasi verbal atau teks. Penyajian difokuskan pada konsep-konsep dari materi yang dibahas. ${ }^{13}$ Meski telah menyiapkan rancangan pembelajaran dengan baik, namun saat proses presentasi kelas masih ada peserta didik yang kurang memperhatikan apa yang disampaikan guru. Akibatnya, peserta didik belum memahami secara utuh apa yang telah

\footnotetext{
${ }^{13}$ Abdul Majid, Strategi pembelajaran. (Bandung: Remaja Rosdakarya, 2013) 185- 186
} 
disampaikan oleh guru. Guru yang melihat kondisi tersebut, sebenarnya sudah tidak tinggal diam, dan langsung menegur peserta didik untuk kembali fokus. Yang dilakukan guru tersebut, merupakan bagian dari proses pembelajaran kooperatif. Dimana, salah satu ciri khas dari pembelajaran kooperatif adalah terjadinya komunikasi. Sebagaimana diungkapkan Agus Suprijono, bahwa ada lima hal unsur pembelajaran kooperatif, dimana salah satunya adalah terjadinya komunikasi. ${ }^{14}$

Kemudian, yang juga harus diperhatikan dalam kegiatan presentasi kelas adalah penguasaaan materi pembelajaran. Guru harus benar-benar memahami dan menguasai materi, agar pelaksanaan pembelajaran bisa efektif. Sehingga nantinya tidak banyak pertanyaan yang muncul dari peserta didik. Kondisi di SD Darus Sholah baik di kelas 1 maupun kelas 4, terutama pada saat proses presentasi kelas tidak terlalu banyak muncul pertanyaan dari peserta didik. Guru mampu menjabarkan dan menjelaskan materi pembelajaran yang akan dibahas, sehingga guru bisa segera melaksanakan proses pembelajaran dengan menggunakan tipe STAD. Sehingga apa yang dilakukan guru tersebut merupakan bagian dari pembelajaran kooperatif. Sebagaimana diungkapkan oleh Agus Suprijono bahwa salah satu unsur atau ciri khas dari pembelajaran kooperatif adalah tanggung jawab perseorangan. ${ }^{15}$ Artinya, tidak hanya peserta didik yang bertanggung jawab untuk menyelesaikan tugas yang diberikan guru, namun guru memiliki tanggung jawab perseorangan untuk memahami materi kemudian menyampaikannya dengan baik kepada peserta didik.

\section{Belajar Tim Dalam Pembelajaran Tematik Terpadu Tema 7 Sub Tema} 1 Kelas I dan Tema 8 Sub Tema 2 Kelas IV SD Darus Sholah Jember.

Sintaks yang kedua dari pembelajaran kooperatif dengan menggunakan strategi STAD adalah belajar dari tim. Belajar dalam tim merupakan bagian proses inti dari kegiatan STAD, sebab dalam kegiatan

\footnotetext{
${ }^{14}$ Agus Suprijono. cooperative learning.... Hal 77-80.

${ }^{15}$ Agus Suprijono. cooperative learning..... Hal 77-80
} 
ini, peserta didik ditekankan mampu melakukan proses kerjasama yang baik diantara anggota kelompoknya. Kelompok yang telah dibentuk oleh guru, sebenarnya sudah menunjukkan keberimbangan. Hal ini terlihat dari proses pembagiannya yang memperhatikan beberapal hal, seperti bobot nilai masing-masing peserta didik, serta jenis kelamin.

Dengan komposisi yang berimbang tersebut, diharapkan masingmasing anggota kelompok akan mampu bekerjasama dengan baik, dan satu dengan yang lain akan saling membantu. Selain itu, dengan kelompok yang heterogen diharapkan peserta didik akan mampu menurunkan ego masingmasing, dan peserta didik yang memiliki kemampuan diatas rata- rata dapat membimbing peserta didik yang lain. Apa yang terjadi di SD Darus Sholah, model pembagian kelompok tersebut sudah menggambarkan pembelajaran kooperatif sebagaimana yang disampaikan oleh Robert E Slavin, salah satu karakteristik pembelajaran kooperatif adalah kesempatan sukses bersama. Seluruh anggota kelompok mendapatkan kesempatan yang sama untuk berkontribusi terhadap suksesnya kelompok. Sehingga, suksesnya sebuah kelompok merupakan sukses bersama seluruh anggota kelompok. ${ }^{16}$ Inilah yang diyakini oleh Slavin bahwa pembelajaran kooperatif juga dapat meningkatkan prestasi para peserta didik dan juga akibat positif lainnya, yakni dapat mengembangkan hubungan antar kelompok, penerimaan terhadap teman sekelas yang lemah bidang akademik, dan meningkatkan rasa harga diri. ${ }^{17}$

Dari paparan data yang telah disampaikan oleh peneliti, memang terjadi banyak dinamika yang terjadi pada saat proses belajar dalam tim. Seperti ada beberapa anggota di beberapa kelompok yang terlihat belum serius dalam proses pembelajaran, kemudian masih ada yang terlihat berjalan ke kelompok yang lain dan menggunya, bahkan ada pula yang tidak segera faham. Disinilah kemudian, guru sebagai fasilitator dalam proses

\footnotetext{
${ }^{16}$ Robert E Slavin. Cooperative Learning.... Hal 26- 28.

${ }^{17}$ Robert E Slavin. Cooperative Learning.... Hal 26- 28.
} 
pembelajaran kooperatif harus mampu mengendalikan situasi kelas. Guru tidak boleh hanya berdiam diri saja di depan kelas, tanpa melakukan proses kontrol saat proses pembelajaran.

Meski terjadi banyak dinamika saat proses belajar dalam tim, namun secara keseluruhan, peserta didik baik di kelas 1 maupun kelas 4 SD Darus Sholah menunjukkan adanya proses komunikasi dan interaksi antar anggota kelompok. Saat mengerjakan tugas dari guru, di masing-masing kelompok rupanya sudah ada pembagian tugas masing-masing peserta didik. Misalnya, ada yang mencari jawaban di buku paket, kemudian ada yang bertugas menulis jawaban tersebut, dan ada yang mengkoreksi ulang. Dinamika lain yang menunjukkan adanya pembelajaran kooperatif adalah peserta didik yang memiliki kemampuan tinggi, mampu menjadi tutor bagi peserta didik yang memiliki kemampuan rendah. Mereka saling membantu agar semua anggota kelompok mampu mengerjakan tugas dengan baik.

Dinamika tersebut menurut Agus Suprijono menunjukkan pembelajaran kooperatif. Hal ini terlihat dari beberapa indikator, diantaranya: munculnya saling ketergantungan positif (positive interdependence), yakni menunjukkan bahwa dalam pembelajaran kooperatif ada dua pertanggung jawaban. Pertama, mempelajari bahan yang ditugaskan bersama kelompok dan kedua, menjamin semua anggota kelompok secara individu mempelahari bahan yang ditugaskan.

Dengan begini, tentu masing-masing anggota akan bisa bekerjasama dengan baik. Kemudian, tanggung jawab perseorangan membentuk semua anggota kelompok menjadi pribadi yang kuat. Tanggung jawab perseorangan adalah kunci untuk menjamin semua anggota yang diperkuat oleh kegiatan belajar bersama. Lalu, interaksi promotif yang mampu menghasilkan saling ketergantungan positif, karena masing-masing anggota bisa saling membantu, saling memberi informasi, saling mengingatkan, saling percaya, dan saling memotivasi untuk meraih keberhasilan. 
Komunikasi antar anggota juga terjadi dalam pembelajaran ini, dimana unsur ini mengajari bagaimana masing-masing anggota bisa berinteraksi. Ini membantu untuk melatih kecerdasan sosial masing-masing anggota. Sebab, satu dengan yang lain harus saling menerima dan mendukung untuk meminimalisir konflik dan menyelesaikan tugas secara bersama-sama. ${ }^{18}$ Dinamika tersebut jika melihat teori yang disampaikan Robert E Slavin juga telah menunjukkan pembelajaran kooperatif. Menurut Slavin, pembelajaran kooperatif memiliki enam karakteristik, yakni: Tujuan kelompok, tanggung jawab individual, kesempatan sukses bersama, kompetisi tim, spesialisasi tugas, dan adaptasi. ${ }^{19}$

Jika melihat belajar dalam tim di kelas 1 dan 4 SD Darus Sholah, telah menujukkan adanya tanggung jawab individual, dimana setiap peserta didik mengerjakan tugas dari guru. Kemudian seluruh anggota kelompok memiliki kesempatan sukses bersama, sebab saat mengerjakan tugas mereka saling membantu dan bekerjasama, sehingga seluruh anggota kelompok khususnya yang memiliki kemampuan rendah, bisa sukses bersama-sama.

Selain itu, dengan pembentukan kelompok tersebut secara otomatis akan tercipta kompetisi tim. Seluruh kelompok atau tim akan berusaha semaksimal mungkin memperoleh nilai yang baik, sebab pada akhirnya guru akan memberikan apresiasi kepada tim yang terbaik. Dan yang tidak kalah pentingnya adalah, dengan belajar dalam tim yang terdiri dari beberapa karakter peserta didik, maka akan mengajari peserta didik untuk beradaptasi atau menyesuaikan diri. Mereka tidak boleh lagi memaksakan kehendaknya, peserta didik harus mampu mengendalikan ego, dan tidak ada lagi dominasi masing-masing anggota kelompok.

\footnotetext{
${ }^{18}$ Agus Suprijono. cooperative learning.... Hal 77-80

${ }^{19}$ Robert E Slavin. Cooperative Learning.... Hal 26- 28
} 


\section{Tes individu Dalam Pembelajaran Tematik Terpadu Tema 7 Sub Tema}

\section{Kelas I Dan Tema 8 Sub Tema 2 Kelas IV SD Darus Sholah Jember.}

Tes individu merupakan sintaks ketiga dalam pembelajara kooperatif dengan menggunakan strategi STAD. Tes individu merupakan bagian dari proses evaluasi pembelajaran terhadap peserta didik yang telah mengerjakan tugas dari guru. Tugas tersebut dikerjakan secara bersama-sama oleh peserta didik dalam kegiatan belajar dalam tim atau kelompok.

Tes individu dilakukan untuk mengetahui sejauh mana kemampuan masing-masing peserta didik yang telah disebar ke dalam beberapa kelompok belajar. Tes ini biasanya dilakukan setelah dua kali proses materi pembelajaran. Pada bagian tes individu ini, peserta didik harus memahami betul bahwa usaha dan keberhasilan mereka nantinya akan memberikan sumbangan yang sangat berharga bagi kesuksesan kelompok. Untuk itulah, dalam tahapan ini setiap peserta didik tidak diperbolehkan untuk saling membantu dalam mengerjakan kuis/soal. Sehingga tiap peserta didik bertanggung jawab secara individu untuk memahami materinya. Kondisi tersebut berbeda dengan belajar dalam tim, dimana seluruh anggota kelompok bisa saling membantu dalam mengerjakan tugas dari guru.

Dengan model tes individu ini, diharapkan masing-masing peserta didik yang telah belajar dalam tim bisa bertanggung jawab atas hasil yang mereka raih nantinya. Sebab, hasil tes individu peserta didik akan berpengaruh terhadap skor kelompok nantinya. Harapannya, dengan tanggung jawab individual tersebut, masing-masing peserta didik akan berusaha semaksimal mungkin menjawab soal/kuis yang diberikan guru. Jika hasil mereka kecil, tentu ini akan berpengaruh terhadap skor akhir kelompok mereka. Di SD Darus Sholah, tes individu dilakukan guru dengan dua cara yakni tes verbal dan tulis. Untuk tes verbal dilakukan oleh guru kelas 1, sebab model tes individu tersebut dinilai lebih efektif dan tepat untuk digunakan di kelas 1 . Karena bentuknya verbal, maka masing-masing 
peserta didik yang ditanyakan oleh guru bisa langsung menjawab pertanyaan tersebut.

Pada saat menjawab tersebut, ada beberapa peserta didik yang secara spontan menjawab pertanyaan guru, meskipun yang bersangkutan belum ditunjuk. Melihat kondisi tersebut, guru meminta kepada peserta didik yang belum ditunjuk, untuk diam dan tidak menjawab pertanyaan sebelum ditunjuk. Sementara di kelas 4, model tes individu menggunakan tes tulis. Sebelum guru membagikan tugas individu tersebut, guru mengingatkan kepada peserta didik agar tidak saling bekerjasama dan membantu dalam mengerjakan tugas.

Hal itu dimaksudkan, agar guru bisa mengetahui sejauh mana perkembangan belajar dan pengetahuan yang didapat peserta didik dengan menggunakan strategi STAD. Hasil tersebut akan dijadikan guru sebagai bahan evaluasi, apakah strategi STAD cukup efektif dilaksanakan pada kegiatan pembelajaran selanjutnya. Dari hasil paparan data, pada tes individu ini, ternyata peserta didik di kelas 4, cukup antusias dalam mengerjakan tugas yang diberikan oleh guru. Bahkan, antar peserta didik tidak bekerjasama saat mengerjakan tugas. Mereka melaksanakan instruksi guru saat mengerjakan tugas, sehingga kondisi kelas sangat kondusif.

Kondisi di kelas 1 dan kelas 4 SD Darus Sholah pada tes individu mencerminkan pembelajaran kooperatif. Dimana menurut Agus Suprijono, pembelajaran kooperatif bisa didefinisikan sebagai falsafah mengenai tanggung jawab pribadi dan sikap menghormati sesama. Perserta didik bertanggung jawab atas belajar mereka sendiri, dan berusaha menemukan informasi untuk menjawab pertanyaan yang diberikan kepada mereka. ${ }^{20}$

Pada sintaks tes individu, guru tidak hanya memberikan soal saja kepada peserta didik, namun guru juga memberikan nasihat kepada peserta didik. Nasihat itu diberikan oleh guru karena soal yang diberikan kepada

\footnotetext{
${ }^{20}$ Agus Suprijono. cooperative learning.... Hal 74
} 
peserta didik berisi tentang cerita Malin Kundang yang dikenal sebagai anak yang durhaka. Guru menasihati peserta didik agar sikap Malin Kundang yang durhaka dengan tidak mengakui orang tuanya, merupakan sikap tidak terpuji dan tidak boleh ditiru oleh peserta didik. Nasihat ini penting diberikan, agar peserta didik mendapatkan pesan dari cerita rakyat tersebut. Dikawatirkan, jika tidak diberikan nasihat, justru peserta didik akan meniru perbuatan tersebut. Apa yang dilakukan guru tersebut merupakan bagian dari pembelajaran kooperatif. Adanya sikap saling ketergantungan positif, kemudian proses komunikasi antara guru dan peserta didik, merupakan bagian dari unsur atau ciri khas dari pembelajaran kooperatif.

\section{Skor Pengembangan Individu Dalam Pembelajaran Tematik Terpadu Tema 7 Sub Tema 1 Kelas I dan Tema 8 Sub Tema 2 Kelas IV SD Darus Sholah Jember}

Skor pengembangan individu merupakan sintaks atau langkah ke empat dari strategi STAD. Skor pengembangan individu biasanya dihitung berdasarkan skor dasar dan skor tes. Untuk skor dasar biasanya guru mengambil dari nilai rapot sebelumnya, sedangkan skor tes biasanya diambilkan dari gabungan skor tes yang telah dilakukan. Di SD Darus Sholah, skor pengembangan individu diambilkan dari nilai sebelum dilaksanakannya pembelajaran kooperatif dengan strategi STAD, kemudian pada saat proses, dan nilai akhir. Dengan penggabungan nilai tersebut, guru bisa melihat sejauh mana kemudian hasil belajar masing-masing peserta didik dan nilai kelompok.

Skor gabungan tersebut, kemudian akan dijumlah secara keseluruhan untuk menjadi skor kelompok. Sehingga dengan munculnya skor kelompok tersebut, akan dijadikan dasar oleh guru untuk memberikan apresiasi kepada tim atau kelompok terbaik. Dengan model tersebut, maka akan tercipta persaingan antar kelompok. Persaingan tersebut bentuknya positif, yakni seluruh kelompok di kelas akan bersaing menjadi yang terbaik. Sehingga dalam setiap proses pembelajaran, kelompok yang terbaik bisa 
akan berubah karena seluruh peserta didik akan termotivasi untuk menjadi yang terbaik.

Kondisi tersebut menunjukkan adanya kompetisi tim yang juga menjadi ciri khas dari pembelajaran kooperatif. Dimana, dengan menekankan pada pembelajaran berbentuk kelompok, akan berdampak terhadap kompetisi atau persaingan masing-masing kelompok. Sehingga dengan munculnya sebuah kompetisi tim tersebut, maka bisa dijadikan sarana untuk memotivasi peserta didik agar bisa bekerjasama dengan baik dengan seluruh anggota kelompok.

\section{Penghargaan Tim Dalam Pembelajaran Tematik Terpadu Tema 7 Sub} Tema 1 Kelas I dan tema 8 sub tema 2 Kelas IV SD Darus Sholah Jember.

Penghargaan dalam tim merupakan sintaks kelima dalam strategi STAD. Penghargaan dalam tim merupakan bentuk apresiasi atau penghargaan yang diberikan guru terhadap peserta didik dan kelompok atau tim dalam setiap proses pembelajaran. Penghargaan tersebut diberikan agar dapat memotivasi para peserta didik. Penggunaan sistem skor dalam model STAD adalah untuk lebih menekankan kemajuan daripada prosentase jawaban yang benar. Dengan model begini, akan memacu peserta didik untuk lebih maju dan lebih baik dari kegiatan belajar sebelumnya.

Dari paparan data dan temuan di lapangan, bentuk penghargaan yang diberikan guru kepada kelompok terbaik dengan memberikan hadiah. Hadiah tersebut berupa benda yang memiliki manfaat secara kepada peserta didik, seperti buku dan alat tulis. Hadiah atau apresiasi yang diberikan guru tersebut merupakan ciri dari pembelajarna kooperatif. Diharapkan, dengan hadiah yang diberikan akan muncul motivasi dari peserta didik untuk memperoleh nilai yang lebih baik. Inilah yang kemudian disebut oleh Imas kurniasih dengan kelebihan dari kelebihan STAD. Yakni dengan pembelajaran bersama-sama kemudian nantinya ada apresiasi atau penghargaan dari guru berupa hadiah, maka peserta didik dengan sendirinya 
akan percaya diri dan meningkatkan kecakapan individunya. Selain itu, interaksi sosial yang terbangun dalam kelompok, dengan sendirinya peserta didik akan belajar dalam bersosialisasi dengan lingkungannya (kelompok). ${ }^{21}$

\section{SIMPULAN}

Hasil dari paparan data dan analisis serta pembahasan hasil temuan dapat disimpulkan, yaitu: 1) Pada tahap pertama diawali dengan presentasi guru. guru memulai materi pelajarannya dengan memberikan cerita yang berkaitan dengan materi yang akan disampaikan. Selain itu guru memulai kegiatan pembelajaran kooperatif dengan mereview ulang materi sebelumnya. Kegiatan belajar dalam tim. 2) Guru menyiapkan lembaran kerja sebagai pedoman bagi kerja kelompok. Sehingga semua anggota menguasai dan masing-masing memberikan kontribusi selama tim bekerja. Dalam proses belajar itulah kemudian, guru melakukan pengamatan, memberikan bimbingan, dorongan, dan bantuan bila diperlukan. Kerja tim ini merupakan ciri terpenting dari STAD. 3) Tes individu, yang bertujuan untuk melakukan evaluasi terhadap masing-masing individu dalam kelompok. 4) Skor pengembangan individu, yakni guru menggabungkan skor dasar yang diambilkan dari nilai sebelumnya, dengan skor akhir yang diambilkan dari skor proses dan akhir saat dilaksanakannya pembelajaran. 5) Penghargaan tim, yakni penghargaan tim ini didasarkan kepada penilaian individu di masing-masing kelompok. Penilaian individu tersebut akan memunculkan penilaian kelompok rekapitulasi untuk penilaian kelompok tersebut, didasarkan kepada penilaian individu masing-masing kelompok.

\footnotetext{
${ }^{21}$ Imas kurniasih dan Berlin Sani, Ragam Pengembangan Model Pembelajaran (Kata Pena, 2015) . Hal. 22-23
} 


\section{DAFTAR PUSTAKA}

David W. Johnson and Roger T. Johnson. Cooperative Learning. USA: University of Minnesota.

Imas kurniasih dan Berlin Sani. Ragam Pengembangan Model Pembelajaran. Kata Pena.

Iskandar. Metodologi Penelitian Kualitatif, Jakarta: GP. Press. 2009.

Majid, Abdul. Strategi Pembelajaran. Bandung: Remaja Rosdakarya, 2013.

Miles and Hubberman. Qualitative Data Analysis United State of Amerika: Arizona State University, 2014

Observasi di Jember Tanggal 4 Januari 2020.

Permendikbud Nomor 66 Tahun 2013 tentang Standar Penilaian Pendidikan

Ricard Dunne dan Ted Wragg. Pembelajaran Efektif. Terjemahan Anwar Yasin. Jakarta: Gramedia Widiasarana Indonesia. 1996.

Rusman. Model-Model Pembelajaran: Mengembangkan Profesionalisme Guru. Jakarta: Raja Grafindo Persada, 2012.

Slavin, Robert E. Cooperative Learning: Theory, Reserach and Practice. London: Allymand Bacon. 2005.

Sugiyono. Metode penelitian kuantitatif, kualitatif, dan $R \& D$ Bandung: CV Alfabeta,2017.

Wawancara di Jember Tanggal 2 Maret 2020. 